\title{
Marital Rape di Kampung Nelayan: Pandangan Sosiologis
}

\author{
H. M. Djunaidi Ghony
}

Penulis adalah Dosen Fakultas Tarbiyah UIN Malang, kandidat Doktor pada UIN Sunan Kalijaga Yogyakarta

\begin{abstract}
This research of marrital rape at fisherman community on Sendangbiru aims to find out the answers of these problems: (1) Does the marrital rap happen in fisherman community so that there are a lot of wifes raising to be divorced?, (2) What kinds of Factors which can push the potential opportunity of woman become a victim in family life?, (3) How do the fisherman community view the marital rap?, (4) What type of marrital rap among fisherman community can be define?, and (5) What are the woman efforts in order to protect from marital rap?

By using the sociological paradigm and of the case approach and the descriptivequalitative analysis, this research find out that: (1) There are marital rape realities in fisherman community environment; (2) Some factors that pushing the marital rape are: sociological, anthropological and psychological factors that sustained by understanding of normative and textual of religion doctrine; (3) the Marrital rape can be enforcing rapist, physical and psychical victim, and prostitution rape, that is woman become "social-prostitute". By the other type the caracteristic of marrital rape can be defined as: anger rape, exploitation rape, and humanity crime or sadistic rape; (4) The fisherman community view that this reality showing the stereo typing socialize and the social tradition influenced by textualist dogma of religion, namely the woman considered to be "steward" and " subordination" of men (the husband); and (5) Meanwhile, the majority of woman is over a barrel in answering the problems, so that they look this facts as factual reality, as what religion (Cristien and Islam) desire. Partly among the
\end{abstract}


woman try to solve the problems through the law, but they just remain to be find "the justice" in gender deflected.

Wacana keperempuanan belakangan ini mendapatkan respon yang cukup tinggi, terutama persoalan krisis sosial berupa meningkatnya kekerasan terhadap perempuan, seperti penindasan terhadap buruh-buruh perempuan, perlakuan kasar anak pada ibunya, perempuan umumnya yang rela dijadikan komoditas bagi masyarakat industri, dan penganiayaan suami terhadap isteri. Gejala sosial berupa perkosaan menunjukkan adanya hubungan antara berbagai macam kekerasan lain yang dilakukan terhadap perempuan, seperti perkosaan dan pemukulan, kematian akibat maskawin di India, perusakan atau pemotongan organ intim perempuan di Afrika, dan pembuatan pomografi.

Kekerasan terhadap perempuan di Indonesia belakangan memang cukup memprihatinkan, karena setiap lima jam telah terjadi perkosaan terhadap perempuan. Lebih memperihatinkan lagi, perkosaan tersebut $60 \%$ korbannya adalah anak-anak di bawah umur 15 tahun, sementara pelakunya $60 \%$ adalah orang yang dikenal baik oleh korban.' Berkaitan dengan kekerasan perempuan dalam keluarga, menurut laporan LBH-APIK Jakarta, antara tahun 1996 sampai tahun 2000, telah menangani kasus kekerasan dalam rumah tangga sebanyak 400 kasus. $^{2}$

Kita dapat melihat juga kekerasan terhadap perempuan dalam rumah tangga ini di berbagai negara di seluruh dunia; di Peru $70 \%$ dari seluruh kejahatan yang dilaporkan kepada polisi menyangkut perempuan yang dipukul oleh mitranya; di Lima, kota dengan sujuh juta penduduk, dilaporkan dalam tahun 1987 telah terjadi perkøsaan sebanyak 168.970 kasus; dan di India delapan dari sepuluh isteri mengalami kekerasan dalam rumah tangganya. Rumah ternyata tempat yang paling berbahaya bagi perempuan. ${ }^{3}$

Melihat pentingnya permasalahan tersebut, dalam Konvensi PBB tentang "Penghapusan Kekerasan terhadap Perempuan" dinyatakan bahwa perkosaan tidak terbatas pada yang terjadi di luar rumah atau di luar perkawinan, tapi juga meliputi perkosaan dalam rumah tangga (marital rap). Hal yang demikian ini terjadi apabila hubungan seksual dilakukan tidak atas kehendak dan persetujuan perempuan, dengan persetujuan perempuan namun di bawah ancaman; dan atau dengan persetujuan namun melalui penipuan. ${ }^{4}$ Pada sisi lain, kekerasan dalam 
rumah tangga (domestic violence) merupakan bagian dari kekerasan dalam keluarga (family violence). Perilaku kekerasan ini mencakup kekerasan fisik, psikologis/emosional, seksual dan kekerasan ekonomi. Dengan demikian dapat dipahami bahwa marital rap termasuk dalam bentuk kekerasan terhadap perempuan yang terjadi di rumah dan dilakukan oleh suami sendiri, baik dalam bentuk fisik, mental, sosial atau ekonomi.

Berangkat dari gambaran tentang kekerasan terhadap perempuan seperti diuraikan. peneliti tertarik untuk melakukan riset mengenai marital rap di kampung nelayan Sendang Biru Desa Tambakrejo Kecamatan Sumbermanjing Wetan Kabupaten Malang. Kegelisahan akademik yang lain dan mendorong peneliti untuk melakukan penelitian di daerah ini ialah adanya data di Pengadilan Agama, antara Januari sampai Agustus 2000, menunjukkan bahwa perceraian yang diakibatkan oleh faktor ketidakharmonisan keluarga dan ketidakbertanggungjawaban laki-laki, masing-masing sebanyak 1.903 dan 781 kasus. ${ }^{5}$ Sementara data di Kantor Urusan Agama (KUA) Kecamatan Sumbermanjing Wetan menunjukkan sejak Januari hingga September 2000 terdapat kasus talak (diajukan pihak suami) dan cerai (diajukan pihak isteri) masing-masing 48 dan 68 kasus. ${ }^{6}$ Dari data ini, tampak dengan jelas bahwa pihak perempuan (isteri) lebih banyak mengajukan gugat cerai, bila dibandingkan dengan talak yang diajukan pihak laki-laki.

Penelitian ini berusaha mengkaji pandangan sosiologis terhadap marital rap di kampung nelayan di Sendang Biru Kabupaten Malang yang secara spesifik fokus permasalahannya adalah: (1) Apakah marital rap terjadi di kalangan masyarakat nelayan sehingga banyak istri yang mengajukan gugat cerai?, (2) Faktor-faktor apa saja yang dapat mendorong adanya peluang potensial perempuan menjadi korban kekerasan dalam keluarga?, (3) Bagaimana pandangan masyarakat nelayan tentang marital rap?, (4) Bagaimana tipe-tipe marital rap di kalangan masyarakat nelayan?, dan (5) Bagaimana usaha-usaha perempuan masyarakat nelayan agar terhindar dari marital rap? Berangkat dari permasalahannya, penelitian ini bertujuan untuk menggali informasi terjadinya marital rap di kalangan masyarakat nelayan dan faktor-faktor potensial yang mendorong terjadinya marital rap, pandangan masyarakat nelayan terhadap 
marital rap, memberikan tipologi marital rap, serta usaha-usaha perempuan nelayan dalam upaya terhindar dari marital rap.

\section{Metode dan Prosedur Penelitian}

\section{a. Pendekatan, Metode Pengumpulan dan Analisis Data}

Sebagai penelitian kasus mengenai fenomena sosial, penelitian ini menggunakan pendekatan kualitatif yang memusatkan perhatiannya pada prinsipprinsip umum yang mendasari perwujudan satuan-satuan gejala yang ada dalam kehidupan nelayan. Sebagaimana sifatnya, penelitian kasus bertujuan untuk mempertahankan keutuhan (the wholness) dari suatu obyek, data yang dikumpulkan, dipelajari sebagai suatu keutuhan dan keseluruhan untuk mengembangkan pengetahuan yang mendalam mengenai obyek yang bersifat ekploratif dan deskriptif.? Oleh sebab itu, penelitian ini bergantung pada kemampuan observasi, wawancara dan interpretasi. ${ }^{8}$

Dengan demikian, peneliti dalam hal ini bertindak sebagai instrumen penelitian yang didukung oleh observasi partisipatoris dan wawancara mendalam yang kemudian ditulis dalam bentuk catatan-catatan dengan model catatan pengamatan (CP), catatan teoritis (CT) dan catatan metodologis (CM) tentang realitas di lapangan." Dengan demikian, metode yang digunakan untuk mengumpulkan data ialah wawancara riwayat hidup (life history interview), observasi partisipan, dan Focus Group Discussion (FGD).

Analisis data dalam penelitian ini dilakukan dengan dua tahap. Pertama, dilakukan pada saat peneliti berada di lapangan dengan cara memberi kode (coding) dan memisahkan data sesuai dengan tipologinya. Kedua, analisis dilakukan setelah data terkumpul seluruhnya dengan menggunakan deskriptifkualitatif. Melalui analisis dua tahap ini, diharapkan dapat diperoleh gambaran yang jelas dan utuh mengenai pandangan sosiologis. 


\section{b. Lokasi dan Informan Penelitian}

Penelitian ini difokuskan pada komunitas pemukiman para nelayan di Kabupaten Malang Selatan, khususnya Dusun Sendangbiru Desa Tambakrejo Kecamatan Sumbermanjing Wetan, yang merupakan wilayah terkonsentrasinya para nelayan di daerah Malang Selatan. Kawasan ini dipilih karena pola pemukiman komunitas nelayan pada umumnya terkonsentrasi pada sistem orbitrasi pengelompokan dalam suatu kawasan, dengan tempat tinggal yang tidak teratur, berhimpitan antara satu rumah dengan rumah yang lain, dan terkesan kumuh. Dari komunitas sosial seperti ini, secara sosiologis mudah terjadi masalah-masalah sosial, seperti marital rape.

Alasan lain pemilihan lokasi ini ialah realitas struktur sosial komunitas nelayan yang pada umumnya merupakan nelayan pekerja (pandega), bukan pemilik kapital dan tidak memiliki keahlian, sehingga para nelayan lebih banyak mengandalkan kemampuan fisiknya dalam melakukan tugasnya. Dengan kondisi ini, peneliti ingin menggambarkan bahwa cara kerja yang tradisional dan tidak profesional tersebut mengakibatkan para nelayan menguras seluruh perhatian dan tenaganya untuk berlayar pada sore dan malam hari. Pada kondisi sosial seperti ini akan mudah terjadi marital rape dalam kehidupan keluarga nelayan.

Pada sisi lain, daerah ini mempunyai dua pola struktur sosial dan membentuk pola budaya yang berbeda. Di tepi pantai, dimana kebanyakan rumahnya terbuat dari anyaman bambu (Jawa: gedhek), dihuni oleh para nelayan pendatang dan mayoritas beragama Islam dan berpendidikan rendah. Sementara di perkampungan, dimana kebanyakan rumahnya sudah mulai tertata rapi dan mayoritas rumah "gedongan", dihuni oleh penduduk asli dan mayoritas beragama Kristen yang berpendidikan tinggi. Dua pola struktur sosial dan keyakinan yang berbeda tersebut menarik perhatian peneliti untuk melihat struktur keluarga dalam komunitas masyarakat yang berbeda.

Dari jumlah penduduk 4.156 jiwa, terdiri dari 2.100 laki-laki dan 2.056 perempuan, 1.074 Kepala Keluarga (KK) yang menyebar dalam 2 dusun, 5 Rukun Warga (RW) dan 20 Rukun Tetangga (RT) di daerah ini, informan penelitian difokuskan pada masyarakat sekitar yang menjadi bagian dari komunitas masyarakat nelayan tersebut yang dilihat dari struktur sosialnya ada nelayan juragan, nelayan pekerja, dan nelayan pemilik pada satu sisi, dan masyarakat 
yang berpendidikan rendah dan tinggi pada sisi lain. Secara spesifik, informan ditentukan pada nelayan yang representatif mewakili keragaman kasus dan tergolong pasangan usia subur (PUS). Untuk menjaga kerahasiaan informan, semua nama informan dalam penelitian ditulis bukan dengan nama asli, melainkan nama samaran yang didekatkan dengan nama aslinya.

\section{Perempuan dalam Keluarga dan Masyarakat Nelayan}

Bagi para nelayan, hubungan seksual bukan hanya sebagai kebutuhan biologis melainkan juga sarana "rekreatif" pada saat ada tekanan psikologis ketika akan dan sesudah melakukan tugasnya sebagai nelayan yang banyak menguras hampir semua kemampuan fisiknya. Perempuan adalah tempat dimana mereka dapat melepaskan beban psikologis itu. Isteri yang sah pun menurut hukum, dalam pandangan nelayan, bukan partner untuk membangun rumah tangga, melainkan sebagai tempat melampiaskan kebutuhan biologis, kapanpun mereka menginginkan itu.

Wiji (bukan nama asli) adalah salah satu dari sekian perempuan yang telah difungsikan sebagai tempat "rekreatif" itu. Suami yang dicintainya terkadang melakuk an pemaksanaan seksual, bahkan ketika ia sedang menstruasi. Jika aku menolak, katanya, dia selalu marah-marah, bahkan sempat mengancam akan membunuhnya. Sekalipun pasangan muda itu baru mampunyai seorang anak perempuan yang masih kecil itu, Wiji terpaksa mengajukan gugat cerai dan pulang ke rumah orang tuanya di sebuah desa dekat kawasan Sendang Biru bersama seorang anak perempuan yang semata wayang tersebut.

Mariyem, korban pemerkosaan dalam keluarga yang lain, sekalipun tidak pernah dipukul suaminya, namun dirasakannya suami yang dicintainya dengan sepenuh hati dan dihormatinya itu mempunyai keanehan dalam melakukan hubungan biologis. Keanehan tersebut dirasakannya, karena setiap suaminya akan melakukan pelayaran di sore hari, dia selalu minta dilayani. Sebelum melakukan hubungan itu, katanya lebih Janjut, biasanya Sang Kapten (Juragan Laut: begitu masyarakat biasa menyebut pekerjaan suaminya ini) tersebut makan terlebih dahulu sepuas-puasnya lalau menyeretnya ke dalam kamar. Seperti tampak terburuburu, pengakuan Mariyem, dia melakukan dengan kasar, keras dan cepat ejakulasi. Kebiasaan seperti ini juga sering dilakukan saat dia pulang dari berlayar dan tidak mendapatkan hasil yang memuaskan. Untuk menutupi perilakunya tersebut, Sang 
Kapten membelikan peralatan elektronik yang cukup lux dibandingkan dengan para tetangganya yang lain, mulai dari Tape Recorder, TV berwama, VCD Palayer, hingga Parabola. Otomatis Mariyem tidak pemah merasakan kekurangan materi, dan melupakan kesengsaraan batiniyah itu demi kepentingan hidup keluarganya.

Titik, isteri muda seorang pedagang ikan, mengalami hal yang tidak terjauh berbeda dengan perempuan-perempuan itu. Dari segi materi, sang suami dirasakannya sangat bertanggung jawab, bahkan hampir semua kebutuhan materi dia dan anaknya yang masih duduk di SLTP, selalu dapat dipenuhi. Akan tetapi, dia merasakan sesuatu yang aneh dalam perilaku seksual suaminya. Pada satu saat, menurutnya, suaminya pernah memintanya untuk melakukan oral sex, sesuatu yang sama sekali tidak pemah dia bayangkan untuk pernah melakukannya. Namun demi kepentingan keluarganya, dia tetap melakukan kebutuhan sang suami yang dirasakannya agak nyeleneh tersebut. Tapi rupanya, penyelewengan seksual suaminya tidak hanya berhenti sampai di situ, sebab pada waktu yang lain, sang suami pernah minta dilayani lewat belakang (anal sex).

Realitas penyelewengan dan kekerasan terhadap isteri dalam komunitas masyarakat nelayan tidak hanya berhenti sampai di situ, sebab dalam komunitas nelayan pernah terjadi pertukaran isteri antara pasangan $\mathrm{Mu}$ dengan teman seprofesinya. Mu pada awalnya bekerja sebagai nelayan pandega selama tujuh tahun, namun setelah membeli sepeda motor hasil dari pekerjaannya itu, ia kemudian pindah pekerjaan sebagai tukang ojek. Pertukaran pasangan ini, sekalipun salah satu pasangan yang lain tidak bisa bertahan lama (cerai), akan tetapi pasangan Mu dengan pasangan hasil pertukarannya tetap bertahan hingga saat penelitian ini dilakukan.

Kekerasan dalam keluarga di daerah ini lebih memprihatinkan dengan adanya tindak pembunuhan di Kampung Baru Sendangbiru. Pada 1 Mei 1998. seperti diceritakan oleh Puspito Hadi, Ponimin menyiksa dan membunuh isterinya disebabkan berselingkuh dengan laki-laki lain. Mayat sang isteri kemudian digantung di depan pondokan Erwin. Akibat perilaku sadisnya itu, Ponimim mendekam di lembaga pemasyarakatan Polres Kepanjen hingga saat penelitian ini dilakukan.

Sekalipun kondisi perempuan dalam keluarga nelayan seperti dijelaskan sebelum ini, masyarakat nelayan memandang bahwa marital rape hanyalah sebuab mitos, tidak ada dalam realitas masyarakat. Pandangan ini didasarkan 
atas suatu keyakinan dogmatis bahwa suami boleh melakukan hubungan seksual sesuai dengan kehendaknya, sementara isteri dianggap sebagai pelayan suaminya. Dalam hal ini Pdt. Heri Condro Adisaputro mengatakan:

“... saya tidak setuju jika dikatakan bahwa ada pemerkosaan terhadap perempuan dalam arti perempuan sebagai isteri sendiri. Sebab, dalam pandangan agama kami (Gereja Jawi Wetan, pen.), pernikahan itu merupakan rencana dari kehendak Yang Kuasa, karena itu perintah tersebut (kawin, pen.) bersifat kekal, lestari. Karena itulah maka tidak boleh diceraikan ... apapun yang telah dipersatukan oleh Allah, tidak boleh diceraik an oleh manusia ... Namun apabila di tengah perjalanan dalam mengarungi bahtera rumah tangga mengalami masalah, seperti pemaksaan hubungan seksual yang tidak dikehendaki isterinya, hal tersebut bukan berarti perkosaan, tetapi perbuatan ini merupakan tindakan seorang suami yang tidak etis ... bagaimana pun seorang isteri harus mau melayani suaminya kapanpun dikehendakinya..."

Pandangan demikian bukan hanya ada pada pandangan masyarakat Kristen, masyarakat nelayan Muslim pun mempunyai pandangan yang tidak terlalu jauh berbeda dengan pandangan itu. Dalam sebuah perbincangan santai di Takmir masjid, H. Bakar, seorang takmir sebuah masjid daerah ini mengemukakan pandangannya sebagai berikut:

“... menurut saya ya manusia hidup itu yang dipegang adalah peraturan agama, yakni peraturan-peraturan yang telah ditetapkan oleh Allah swt. Seorang isteri itu ya ibarat pakaian bagi suami, demikian pula sebaliknya. Karena itu ya boleh dipakai kapan saja ... Wanita itu ibarat sawah ladangnya, karena itu boleh ditanami kapan saja, asal dengan cara yang baik. Perempuan harus mau apabila suaminya menghendaki berkumpul kapan saja, sebab apabila menolak maka akan dikutuk oleh aturan agama ..."

Sekalipun pandangan agama yang mereka pahami seperti itu, terdapat pranata sosial keagamaan yang berfungsi untuk mendamaikan seluruh permasalahan kekeluargaan, sekalipun hingga saat ini diakui masyarakatnya belum mempunyai fungsi yang optimal. "Apabila ada konflik-konflik rumah tangga, seperti pemukulan atau penganiayaan terhadap isteri," kata Sih Mirso sesepuh Sendangbiru, “...pada umumnya perangkat desa yang paling dominan menyelesaikannya. Padahal sesungguhnya dalam ajaran dan tradisi agama kami ada lembaga sakral (Pranata Gereja) yang bertugas menyelesaikannya, yaitu 
Bapa Seksi ... yang bertugas sebagai saksi, orang tua, dan sekaligus sebagai pembina keluarga ..."

Sementara itu, bagi para perempuan realitas terjadinya kekerasan dalam kelurga ditanggapi dengan cara mengalah, seperti watak mayoritas masyarakat desa ini, dan sebagian kecil yang lain cukup melaporkan pada perangkat desa untuk menyerahkan persoalan yang dihadapinya, seperti yang dilakukan Tinem dalam menyelesaikan permasalahan penyelewengan seksual suaminya. Namun, dalam menyelesaikan permasalahan perselingkuhan seperti yang dilaporkan Tinem, perangkat desa cukup memberikan sanksi berupa tebusan uang kas desa untuk membeli grasak (batu krikil untuk pengerasan jalan). Suatu bentuk keadilan yang ironis!

\section{Diskusi dan Interpretasi}

Melihat realitas kekerasan terhadap perempuan di masyarakat nelayan, bila dipandang dari paradigma yang dipergunakan oleh Johan Galtung, seorang pemikir sosial humanis, disebabkan adanya pola relasi antarmasyarakat, dalam hal ini laki-laki dan perempuan dalam keluarga, yang tidak seimbang, eksploitatif dan represif. Ketidakseimbangan sosial terjadi karena adanya perbedaan segi ada (being), memiliki (having), dan kedudukan dalam struktur sosial. ${ }^{10}$ Dalam kasus penelitian ini, laki-laki sebagai being dipahami sebagai sosok manusia yang ditakdirkan sebagai pemimpin perempuan (jstri) dan berkonsekwensi pada pemahaman perempuan sebagai having (milik) bagi laki-laki. Dalam pandangan demikian inilah terjadi tindak kepemilikan terhadap kaum perempuan sehingga dia bebas melakukan semua yang dia inginkan terhadap hak miliknya tersebut, termasuk meminta untuk dilayani, memukul, dan bahkan melakukan tindakan yang lebih sadis dari itu, seperti mempertukarkan dan membunuh isteri (milik)nya sendiri.

Pada sisi lain, kekerasaan dapat terjadi karena manusia dipengaruhi sedemikian rupa sehingga realisasi jasmani dan mental aktualnya berada di bawah realisasi potensial. Realisasi potensial disini dimaksudkan sebagai apa yang memang mungkin dapat direalisasikan sesuai tingkat wawasan, sumberdaya, dan kemajuan yang sudah dicapai pada jamannya. Penyalahgunaan wawasan, sumberdaya, dan hasil kemajuan untuk tujuan lain disebut sebagai tindak 
kekerasan. " Dalam kasus kita ini, kekerasan yang dilakukan oleh para suami terhadap istri-istrinya disebabkan tingkat wawasan masyarakat nelayan relatif rendah dalam memahami "kemanusiaan" perempuan, sehingga mereka memperlakukan perempuan seperti barang, bukan manusia pada layaknya, yang dapat diperlakukan seperti apa yang diinginkannya, sebagaimana mereka telah memperlakukan itu pada semua kekayaan yang dimilikinya, baju dan sawah.

Tingkat wawasan masyarakat nelayan terhadap kekerasan yang mengandung cakupan yang luas, tidak hanya berupa kekerasan yang bersifat fisik, tapi juga psikologis, struktural dan kultural, ${ }^{12}$ dapat dinilai sangat rendah. Rendahnya wawasan kekerasan ini setidaknya tampak dalam pandangan masyarakat yang menyatakan bahwa perlakukan kasar, tidak senonoh, pemaksaan dalam melakukan hubungan seksual dengan paksa, bukan dianggap sebagai kekerasan.

Sementara itu, wawasan keagamaan masyarakat nelayan terhadap konsep keluarga bersifat tekstualis, dimana para suami dianggap sebagai personifikasi "kepemimpinan Tuhan", kepemimpinan yang didasarkan atas firman Tuhan, dalam keluarga. Pandangan seperti ini yang sering menjadi justifikasi suami untuk menggunakan kepemimpinannya berlaku kasar terhadap istri dengan alasan "mendidik". ${ }^{13}$ Beberapa konsep keluarga yang cukup berpengaruh dalam kehidupan masyarakat nelayan ialah konsep fiqh (hukum Islam) tentang pernikahan, seperti dinyatakan Mas'udi, ${ }^{14}$ yang mana nikah didefinisikan dalam dua bentuk, yaitu kontrak kepemilikan (aqd al-tamlik) dan kontrak diperbolehkannya hubungan seksual (aqd ibahah). Kedua paham ini telah mengakibatkan terjadi kekerasan terhadap istri, sebab dia dianggap sudah dibeli, seperti konsep makan pertama, atau sudah dikontrak alat seksnya, seperti konsep makna kedua. Padahal, masih pandangan Mas'udi, perlakukan seperti itu telah mengakibatkan terjadinya tindak kekerasan terhadap istri dan hukum telah mengajarkan masyarakat untuk bertindak kekerasan.

Pada sisi lain, kekerasan terhadap perempuan dalam keluarga seperti yang tejadi di masyarakat nelayan, bertentang dengan konsep mu'asyarah bi al-ma'ruf (memperlakukan istri dengan cara yang baik) yang mengajarkan kesataraan antarpasangan dalam keluarga dan mengakui sifat kemanusiaan perempuan dalam melakukan hubungan seksual. Sayangnya, pandangan ini belum dipahami oleh 
masyarakat nelayan di Sendangbiru, sehingga mereka menganggap istri sebagai barang yang sudah dibeli melalui akad nikah, dan terjadilah realitas marital rape!

Realitas tersebut secara tipologis dapat berupa perkosaan dalam perkawinan, pemerkosaan disertai tindak kekerasan fisik dan psikis, dan kekerasan dalam bentuk labeling terhadap perempuan yang ditandai dengan pertukaran istri atau menjadikan perempuan sebagai tempat pemuas nafsu seksual. Yang terakhir disebutkan ini, dalam pandangan sosiologis, telah mengakibatkan perempuan melakukan penyimpangan sekunder (secondary deviation), melakukan suatu gaya hidup menyimpang (devianty life style), dan pada akhirnya memilih karir menyimpang (deviant career), sebagai perempuan seks komersial (PSK). Hal ini tampak dalam perilaku masyarakat nelayan yang suka melampiaskan kebutuhan seksualnya pada perempuan lain atau melakukan pertukaran isteri.

Pada sisi lain, kategorisasi kekerasan dalam keluarga ini dapat digolongkan menurut pandangan Suparman Marzuki, yakni tipe perkosaan berupa pemaksaan hubungans eksual seorang suami terhadap istri (angger rape), perkosaan karena keuntungan dan kebergantungan ekonomi dan sosial (exploitation rape), dan kekerasan sadis (sadistic rape) yang memadukan seksualitas dan agresi dalam bentuk kekerasan destruktif.

Melihat cara pandang masyarakat nelayan dalam menanggapi permasalahan marital rape masih tampak menggunakan pendekatan normatiftekstual dalam memahami doktrin-doktri agama (Kristen-Islam) yang menyebabkan mereka terjebak dalam angan-angan sosial yang abstrak. Bagi para Pendeta dan Kyai pandangan tersebut telah mengantarkan mereka berada dalam situasi problematik dalam menghadapi permasalahan yang dihadapi masyarkatnya, yang oleh karenanya masyarakat (terutama kaum perempuan) lebih memilih menyelesaikan permasalahannya pada perangkat desa, dibandingkan pada Pendekata (Gereja) atau Kyai (Masjid), sekalipun masing-masing mempunyai fungsi pranata sosial yang dapat menyelesaikan permaslahan tersebut. 


\section{Kesimpulan}

Berdasarkan temuan-temuan dan diskusi analitis lima permasalahan dalam penelitian ini dapat dijawab dengan kesimpulan berikut:

1. Beberapa kasus kekerasan terhadap istri yang terjadi pada masyarakat nelayan menunjukkan bahwa ada realitas marital rape di lingkungan masyarakat nelayan. Sekalipun yang dapat diungkapkan pada penelitian ini sedikit, akan tetapi, ibarat "gunung es", yang tidak tampak pada fenomena sosial jauh lebih banyak dari tampakannya itu. Oleh karenanya, kekerasan terhadap peempuan dalam keluarga adalah sebuah realitas, bukan mitos.

2. Ada beberapa faktor yang mendorong terjadinya marital rape pada lingkungan masyarakat nelayan, faktor sosiologis, psikologis dan antropologis yang ditopang oleh pemahaman doktrin agama yang normatif-tekstual.

3. Tipologi marital rape dalam masyarakat nelayan dapat berbentuk sebuah pemerkosaan yang disertai pemaksaan, kekerasan fisik dan psikis, dan kekerasan dalam bentuk prostitution rape, yaitu menjadikan perempuan sebagai "pelacur" sosial. Dengan lain model, karaketristik pemerkosaan terhadap isteri dapat dibagi pada anger rape, exploitation rape, dan humanity crime atau sadistic rape.

4. Melihat realitas tersebut, masyarakat nelayan memandang bahwa hal tersebut bukan bentuk kekerasan terhadap isteri, karena dia sebagai "pelayan" dan "subordinasi" suaminya. Pandangan ini masih tampak jelas menggambarkan stero tipe masyarakat dan tradisi sosial yang dipengaruhi oleh dogma agama yang tekstualis.

5. Sebagian besar para istri berada dalam ketidakberdayaannya dalam menanggapi permasalahan tersebut, sehingga mereka memandang kenyataan ini sebagai realitas yang "sebenarnya", seperti keinginan agama (KristenIslam) yang mereka patuhi. Sebaliknya, ada sebagian kecil istri yang berusaha untuk menyelesaikan permasalahan tersebut melalui jalur hukum, baik mengajukan perceraian pada Pengadilan Agama, maupun menganggap cukup dengan menyerahkan permasalahan tersebut pada aparatur desa. 


\section{Endnotes:}

1 Budi Wahyuni. Terpuruk Ketimpangan Gender (Yogyakrta: PKBI DIY dan LAPERA Indonesia, 1997), 56

2 Mursyidah Thahir, Mursyidah. "Pemberdayaan Perempuan", dalam Jumal Pemikiran Islam. (Jakarta: Logos Wacana Ilmu, 2000), 27

3 C. Bunch, Toward a Revision of Women (t.t.: tp., 1990), 6

4 Rifka Annisa, Kami Peduli terhadap Korban Perkasaan (Yogyakarta: Rifka Annisa Women's Crisis Center dan The Ford Foundation, 1997), 240

5 Laporan PA Kabupaten Malang, Agustus 2000

6 Data KUA Kecamatan Sumbermanjing Wetan, September 2000

7 D. Ari, et. al. Intruduction to Research in Education. The Third Edition. (New York: Holt, Rinehart and Wiston, 1985)

8 Rosalia Sciortino, "Pendekatan Sosial dalam Penelitian Kesehatan Reproduksi," dalam Majalah Populasi. Vol. 5. Nomor 2. (Yogyakarta: PPK UGM.,1995), 78-79

9 Lexy J. Moleong, Metodologi Penelitian Kualitatif. (Bandung: PT. Rernaja Rosda Karya, 2000), 154-156

10 H. Mudjia Rahardjo, "Kekerasan dan Kekuasaan dalam Praksis Berbahasa: Memahami Kekerasan dalam Perspektif Galtung", dalam Majalahel-Harakah, Nomor 55/XXV/ April-Juni (Malang: STAIN Malang Press, 2000), 4-5

11 Ibid., 5

12 HM. Djunaidi Ghony, "Agama dan Kekerasan Massa", dalam Majalah el-Harakah, Nomor 55/XXI/April-Juni (Malang: STAIN Malang Press, 2000), I3

13 Nur Elli Hayati, Panduan untuk Pendamping Perempuan Korban Kekerasan: Konseling Berwawasan Gender (Yogyakarta: Pusatak Pelajar dan Rifka Annisa, 2000), 41

14 Masdar F. Mas'udi, Islam dan Hak-hak Reproduksi Perempuan: Dialog Figh Perempuan (Bandung: Mizan, 1997), 107-8

\section{BIBLIOGRAFI}

Alfian,1986. Transformasi Sosial Budaya dalam Pembangunan Nasional. Jakarta: UI Press.

Annisa, Rifka. 1997. "Masihkah Anda Mempercayai Mitos?", dalam Eko Prasetyo dan Suparman Marzuki, ed., Perempuan dalam Wacana Perkosaan.Yogyakarkta: PKBI dan Pustaka Pelajar. 
1997. Kami Peduli terhadap Korban Perkosaan.Yogyakarta:

Rifka Annisa Women's Crisis Center dan The Ford Foundation.

. 1999. Kekerasan terhadap Istri. Yogyakarta: Rifka Annisa

Women's Crisis Center dan The Ford Foundation.

Anshori, Dadang S. 1997. Membincang Feminisme. Bandung: Pustaka Hidayah.

Ari, D. et. al. 1985. Intruduction to Research in Education. The Third Edition.

New York: Holt, Rinehart and Wiston.

AS., Tutik Alawiyah. 1987. Strategi Dakwah di Lingkungan Majelis Ta'lim. Bandung: Mizan.

Boswardono. 1995. "Disiksa Suami: Mengapa Bertahan?”, dalam Majalah Ayah Bunda. Nomor 20, Oktober.

Bunch, C. 1990, "Toward a Revision of Women"

Faqih, Mansour. 1997. "Perkosaan dan Kekerasan: Perspektif Analisis Gender, “ dalam Prasetyo, Eko, dan Marzuki, Suparman, ed. 1997. Perempuan dalam Wacana Perkosaan. Yogyakarta: PKBI dan Pustaka Pelajar.

Faqih, Mansour. 1999. Analisis Gender dan Transformasi Sosial. Yogyakarta: Pustaka Pelajar.

Faridi, Miftah. 1996. Keluarga Bahagia: Peraturan Nikah dan Pembinaan Keluarga. Bandung: Penerbit Pustaka.

Ghony, HM. Djunaidi. 2000. "Agama dan Kekerasan Massa", dalam Majalah el-Harakah, Nomor 55/XX1/April-Juni Malang: STAIN Malang Press.

Glasser, Barnay G., and Anselm L. Strauss. 1995. Penemuan Teori Grounded: Beberapa Strategi Penelitian Kualitatif. Terj. Abdul Syukur Ibrahim dan Makrus Syamsuddin. Surabaya: Usaha Nasional.

Hafidz, Lisa, ed. 1995. Bila Perkosaan Terjadi. Jakarta: Kalyanamitra.

Harried, Bredly. 1996. Frectured Identity, Caneging Pattern of Inequlity. Cambridge: Polity Press.

Hasyim, Syafiq, ed. 1999. Menakar Harga Perempuan: Eksplorasi Lanjut atas Hak-hak Reproduksi Perempuan dalam lslam. Bandung: Mizan.

Hayati, Nur Elli. 2000. Panduan untuk Pendamping Perempuan Korban Kekerasan: Konseling Berwawasan Gender. Yogyakarta: Pusatak Pelajar dan Rifka Annisa.

Hester, M. Lizkeily and Jill Radford.1992. Women Violence and Mile Power. Philadelphia: Open University Press.

Ihromi, T. O. 1995. Kajian Wanita dalam Pembangunan. Jakarta: Yayassan Obor Indonesia. 
Krueger, Richard A. 1998. Focus Groups: A Practical Guide for Applied Research. Newburry Parka: SAGE.

Mas'udi, Masdar F. 1997. Islam dan Hak-hak Reproduksi Perempuan: Dialog

Figh Perempuan. Bandung: Mizan.

Megawangi, Ratna. 1999. Membiarkan Berbeda. Bandung: Mizan.

Moleong, Lexy J. 2000. Metodologi Penelitian Kualitatif. Bandung: PT. Remaja Rosda Karya.

Mosse, Julia Cleves. 1994. Gender dan Pembangunan. Yogyakarta: Rifka Annisa dan Pustaka Pelajar.

Muhajir, Noeng. 2000. Metodologi Penelitian Kualitatif. Yogyakarta: Raka Sarasin.

Niebet, J. and J. Watt. 1994. Studi Kasus: Sebuah Panduan Praktis. Saduran L. Wilardjo. Jakarta: Grasindo.

Prasetyo, Eko dan Suparman Marzuki, ed. 1997. Perempuan dalam Wacana Perkosaan. Yogyakarta: PKBI dan Pustaka Pelajar.

Rahardjo, H. Mudjia. 2000. "Kekerasan dan Kekuasaan dalam Praksis Berbahasa: Memahami Kekerasan dalam Perspektif Galtung", dalam Majalah elHarakah, Nomor 55/XXI/April-Juni Malang: STAIN Malang Press.

S., Soedjito. 1986. Transformasi Sosial Menuju Masyarakat Industri. Yogyakarta: Tiara Wacana.

Schlegel, Stuard A. 1984. Penelitian Grounded dalam Ilmu-ilmu Sosial. Surakarta: FISIP UNS.

Sciortino, Rosalia. 1995. "Pendekatan Sosial dalam Penelitian Kesehatan Reproduksi," dalam Majalah Populasi. Vol. 5. Nomor 2. Yogyakarta: PPK UGM.

Sciortino, Rosalia. 1997. "Agama, Perempuan dan Kesehatan Reproduksi,", dalam Sambutan Seminar Nasional. Yogyakarta, 9-10 April.

Sunardi, ST. 1996. Keselamatan, Kapitalisme, Kekerasan: Kesaksian atas Pradoks-paradoks. Yogyakarta: LkiS.

Sunarto, Kamanto. 2000. Pengantar Sosiologi. Jakarta: Lembaga Penerbit Fakultas Ekonomi Universitas Indonesia.

Taniko, Soeleman B. 1993. Struktur dan Proses Sosial: Suatu Pengantar Sosiologi Pembangunan. Jakarta: PT. RajaGrafindo Persada.

Taslim, Adrian. at. al. 1995. Bila Perkosaan Terjadi. Jakarta: Kalyanamitra.

Thahir, Mursyidah. 2000. "Pemberdayaan Perempuan", dalam Jumal Pemikiran Islam. Jakarta: Logos Wacana Ilmu.

Wahyuni, Budi. 1997. Terpuruk Ketimpangan Gender. Yogyakrta: PKB1 DIY dan LAPERA Indonesia. 